\title{
Ameliorating Effect of Alpha-lipoic Acid on Methotrexate-induced Histological and Biochemical Changes in The Lung of Adult Albino Rat
}

\author{
Original \\ Article \\ Joseph Amin Aziz, Abd-Elmawla Elsayed Aidaros, Ahmed farag Ali, \\ Mohamed Sabry
}

Department of Anatomy and Embryology, Faculty of Medicine, Zagazig University, Zagazig, Egypt

\begin{abstract}
Background: Owing to its antioxidant, anti-inflammatory and anti-fibrotic properties, alpha-lipoic acid (ALA) has been evaluated in a diversity of degenerative diseases and experimental toxicological studies.

Aim of the Work: This study was performed to assess the ability of ALA to reverse the histological and biochemical alterations that take place in the rat lungs after exposure to methotrexate.

Materials and Methods: This study was done using thirty-two male Wistar albino rats $(180-220 \mathrm{~g})$. The animals were divided into four equal groups. The control group: received distilled water by oral gavage for ten days and injected intraperitoneally (i.p.) with $1 \mathrm{ml}$ of physiologic saline $(0.09 \% \mathrm{NaCl})$ solution on the fourth day. ALA group: received ALA ( $200 \mathrm{mg} / \mathrm{kg}$ once daily) dissolved in distilled water and given by oral gavage for ten days. Methotrexate (MTX) group: injected with a single dose of $20 \mathrm{mg} / \mathrm{kg}$ MTX i.p. on the fourth day of the study. MTX+ALA group: received an oral dose of ALA (200 mg/kg) for ten days and a single dose of MTX $(20 \mathrm{mg} / \mathrm{kg})$ i.p. on the fourth day. By the end of the experiment, all the animals were anaesthetized using phenobarbital 3\%. Blood samples were collected to measure c-reactive protein (CRP). The lungs were dissected out and prepared for tissue homogenates, routine histological study and caspase-3 immunohistochemical evaluation. Results: In the MTX group, there were high levels of CPR, glutathione (GSH) and malondialdehyde (MDA) with reduction of superoxide dismutase (SOD) and catalase (CAT) activities. Lung sections revealed marked inflammatory cells infiltration, thickening of interalveolar septa, congested blood vessels, intrapulmonary hemorrhages, abundant collagen fibers and significant expression of caspase-3. In ALA+MTX group, there was an overt improvement in lung histoarchitecture. Additionally, SOD activity. CRP, MDA levels and caspase-3 expression were significantly less.

Conclusion: Administration of ALA can work against oxidative damage in the lung induced by MTX.
\end{abstract}

Received: 18 November 2019, Accepted: 24 December 2019

Key Words: Alpha-lipoic acid, caspase-3, lung, methotrexate, rat.

Corresponding Author: Joseph Amin Aziz, M.D., Department of Anatomy and Embryology, Faculty of Medicine, Zagazig University, Zagazig, Egypt, Tel.: +20 1227527558, E-mail: Joseph.aziz@su.edu.eg - Jaaziz@Zu.edu.eg

ISSN: $1110-0559$, Vol. 43, No.3

\section{INTRODUCTION}

Initially, methotrexate (MTX) has been used in haematological malignancies of childhood; currently, its therapeutic benefits cover a wide range of neoplastic and inflammatory conditions ${ }^{[1]}$. Yet, clinical and experimental studies have demonstrated adverse effects of MTX on the brain ${ }^{[2]}$, kidney ${ }^{[3]}$, liver ${ }^{[4]}$, heart ${ }^{[5]}$, intestine ${ }^{[6]}$, hematopoietic tissue ${ }^{[7]}$ and lungs ${ }^{[8]}$. The pulmonary complications comprise hypersensitivity pneumonitis, interstitial fibrosis and pulmonary nodules ${ }^{[9]}$. Hypersensitivity, immunomodulation, idiosyncrasy, and direct lung toxicity have been implicated in the development of such complications ${ }^{[10,11]}$. Oxidative stress and lipid peroxidation have been also suggested to play the key role in methotrexate-induced lung injury (MILI) ${ }^{[12]}$. MTX administration resulted in oxidative-induced damage in kidney ${ }^{[13]}$, liver ${ }^{[14]}$ and testis ${ }^{[15]}$. Despite its high significance, the impact of MTX on the lungs has not been frequently reported ${ }^{[11]}$.

Alpha-lipoic acid (ALA) is naturally synthetized in human cells. It also exists in animal and vegetables in low amounts ${ }^{[16]}$. ALA is an indigenous cofactor in the mitochondrial pyruvate dehydrogenase complex ${ }^{[17]}$; it efficaciously eliminates reactive oxygen species (ROS) and rebuilds the cellular stores of natural antioxidants such as vitamin $\mathrm{C}$ and reduced glutathione ${ }^{[18]}$. Since it dissolves in both fat and water, ALA can quench free radicals in cytosol as well as in cell membrane ${ }^{[19]}$. Also, ALA hinders lipid peroxidation and chelates heavy metals ${ }^{[20]}$; it additionally possesses anti-inflammatory and antifibrotic activity ${ }^{[15,21]}$. Clinical and animal studies have evidenced the protective role of ALA against different kinds of tissue injury 
particularly those associated with oxidative stress ${ }^{[22-27]}$.

This study was designed aiming at clarifying the possible ameliorating effect of ALA against MILI.

\section{MATERIALS AND METHODS}

\section{Chemicals}

Methotrexate (Mylan) vial $(50 \mathrm{mg} / 2 \mathrm{ml})$ was purchased from Al-Gomhoria pharmaceutical company, Cairo, Egypt. Alpha lipoic acid, commercially Thioctic acid, was obtained in the form of powder from Eva-pharm pharmaceutical company, Egypt.

\section{Animals}

Thirty-two male Wistar albino rats (180-220 g) obtained from the animal house of Zagazig University were selected for this study. The animals were kept in a room illuminated for 12 hours by daylight at a temperature of $25-30^{\circ} \mathrm{C}$, fed a standard rat chow diet and had access to water ad-libitum. Animal care followed the guidelines of the Ethical Committee of Zagazig University and the protocol of the study was approved by the institutional animal care and uses committee of the Zagazig University (ZU-IACUC); number ZU-IACUC $3 \backslash F \backslash 49 \backslash 2019$.

\section{Experimental design}

Animals were randomly allocated into four groups; 8 animals in each one. Control group: received distilled water by oral gavage for ten days and a single i.p. injection with $1 \mathrm{ml}$ of physiologic saline $(0.09 \% \mathrm{NaCl})$ solution on the same day of MTX injection. ALA group: received ALA (200 mg/kg once daily) dissolved in distilled water and given by oral gavage ${ }^{[22]}$ for ten days ${ }^{[28]}$. Group III, (MTX group): The rats in this group were injected with a single dose of $20 \mathrm{mg} / \mathrm{kg}$ MTX i.p. on the fourth day of the study ${ }^{[28]}$. MTX + ALA group: Rats received an oral daily dose of ALA $(200 \mathrm{mg} / \mathrm{kg})$ for ten days and a single dose of MTX $(20 \mathrm{mg} / \mathrm{kg})$ i.p. on the fourth day.

After 10 days, all rats were weighed and anaesthetized using sodium thiopental (75 $\mathrm{mg} / \mathrm{kg})$ injected intraperitoneally. Blood samples were withdrawn from the retro-orbital venous plexus to assess the level of CRP. Then a midline thoracic incision was done, the lungs were carefully excised, washed in cool saline, dried and weighed. Lung specimens were prepared for tissue homogenates, histopathological and immunohistochemical evaluation.

\section{Serum $C$ - reactive protein (CRP) assay}

Blood samples were centrifuged at $2000 \mathrm{pm}$. The separated serum kept at $-80^{\circ} \mathrm{C}$. CRP was measured using enzyme-linked immunosorbent assay kits (Biosource International, Nivelles, Belgium).

\section{Tissue biochemical analysis}

The lung specimens were weighed, homogenized in ice-cooled Tris- $\mathrm{HCl}$ buffer ( $\mathrm{pH}$ 7.4) using Teflon-glass homogenizer. The homogenates were centrifuged at 4.000 rpm for 10 minutes at $4^{\circ} \mathrm{C}$. The obtained supernatant was kept at $-80{ }^{\circ} \mathrm{C}$ till the time of analysis. Oxidative stress parameters: MDA, SOD, CAT and GSH were evaluated using colourimetric kits purchased from Bio-diagnostic, Giza, Egypt.

Malondialdehyde (MDA ${ }^{[29]}$ : Lung homogenate is mixed with equal volumes of thiobarbituric (TBA) and trichloroacetic acids and heated at $95^{\circ} \mathrm{C}$ for 30 minutes. MDA, if present, reacts with TBA giving pink thiobarbituric acid reactive products (TBARPs). TBARPs color was assayed at $534 \mathrm{~nm}$. Values were presented as $\mathrm{nmol} / \mathrm{g}$ tissue.

Superoxide dismutase (SOD) activity ${ }^{[30]}$ : SOD inhibits reduction of nitro blue tetrazolium (nitroBT) mediated by phenazinemethosulphate. The absorbance of color is spectrophotometrically measured at $560 \mathrm{~nm}$. The activity of SOD presented as $1 \mathrm{U} / \mathrm{g}$ of tissue.

Catalase (CAT) Tissue Homogenate (CAT ${ }^{[31]}$ : The $\mathrm{H}_{2} \mathrm{O}_{2}$ reacts with 3, 5-Dichloro-2-hydroxybenzene sulfonic acid (DHBS) and 4-aminophenazone to form chromophore, the color of which is inversely proportional to the amount of CAT in the sample. The color is monitored at $240 \mathrm{~nm}$ and the results were expressed in $1 \mathrm{U} / \mathrm{g}$ of tissue.

Reduced glutathione $(\mathrm{GSH})^{[32]}$ : The method is based on the reduction of 2 - nitrobenzoic acid (DTNB) with glutathione (GSH) to produce a yellow compound which can be measured at $405 \mathrm{~nm}$. GSH concentration is directly proportional to the reduced chromogen and is expressed as $\mathrm{nmol} / \mathrm{g}$ of tissue.

\section{Histopathological Examination}

After being fixed in 10\% formalin, the lung tissues were dehydrated using ethyl alcohol in ascending grades $(70 \%$, $80 \%, 90 \%, 95 \%$, and $100 \%$ ) then cleared in xylene, and embedded in paraffin wax. Sections of 4-5 micrometers $(\mu \mathrm{m})$ thickness were cut and stained with hematoxylin and eosin and Masson's trichrome ${ }^{[33]}$. Stained slides were used for histopathological and morphometric evaluations. Photographs were taken using an optical microscope (LeicaICC50W) at the image analysis unit of anatomy and embryology department.

\section{Caspase-3 evaluation ${ }^{[33]}$}

$4 \mu \mathrm{m}$ thickness paraffin sections were deparaffinized in xylene, rehydrated using descending grades of alcohol and washed in phosphate buffer solution (PBS). To inactivate endogenous peroxidase, sections were immersed in $3 \%$ hydrogen peroxide then washed with PBS. After that, slides were boiled in $10 \mathrm{mM}$ citrate buffer $(\mathrm{pH} 6.0)$ for 20 minutes and left to cool at room temperature for another 20 minutes. Nonspecific binding was blocked by adding $5 \%$ bovine serum albumin (BSA) in Tris-buffered saline. Primary anti-caspase-3 antibodies (Novacastra Laboratories Ltd, UK) were applied at a dilution of 1:100 at room temperature for 60 minutes and washed with PBS. The slides after that were incubated with the secondary 
antibodies. Sections were then washed and visualized using 3,3-diaminobenzidine tetrahydrochloride DAB, counterstained with Mayer's hematoxylin and observed under a light microscope.

\section{Morphometric measurements}

Three random sections from 4 rats in each group were examined and photos were analyzed using ImageJ IHC Profiler plugin ImageJ (FIJI) software. For the sections stained by Hematoxylin and eosin, the thickness of interalveolar septa $(\mu \mathrm{m})$ was measured from photos at magnification X400. The area percentage of collagen was assessed in sections stained by Masson's trichrome from photos at magnification X100. The area percentage of Caspase 3 expression was estimated in lung tissue from photos at magnification X400. The results represent the mean \pm standard error on the mean (SEM) of data.

\section{RESULTS}

Serum CPR level: the level of CRP in MTX group was significantly higher than it in the control group $(P<0.001)$. In rats treated with both MTX \& ALA the CPR level significantly declined $(P<0.01)$ when compared with MTX group (Table 1, Figure1).

Tissue biochemical results: MTX induced remarkable changes in oxidative stress markers; it significantly reduced the GSH level and the activity of CAT and SOD $(P<0.001)$. On the other hand, MTX markedly increased MDA level $(P<0.001)$.The combination of ALA with MTX partially restored the redox status; MDA level and SOD activity were significantly elevated $(P<0.001)$ and $(P<0.05)$ respectively. However, non-significant improvement $(P>0.05)$ was observed regarding GSH and CAT (Table 1, Figures 2, 3, 4 and 5).

\section{Light microscopic observations}

Haematoxylin and Eosin: study of lung slides stained with $\mathrm{Hx} \& \mathrm{E}$ demonstrated that both the control (Figures 9 and 10) and ALA treated rats (Figure 11) had normal architecture. Bronchioles of different sizes appeared regular with intact folded mucosa and surrounded by regularly arranged smooth muscle fibers and outer adventitia. Lung parenchyma consisted of alveolar ducts, alveolar sacs and alveoli of different sizes with thin septa. The alveoli were lined by a single layer of two types of cells; squamous, thin cells with flat nuclei (type I pneumocyte) and cuboidal cells with rounded nuclei (type II pneumocyte). The lung exposed to MTX showed destruction of the epithelial lining of the bronchioles and disorganization of the surrounding musculosa (Figure 12). Apparent thickening of the interalveolar septa with mononuclear cells and predominance of type II pneumocytes was also noticed (Figure 13). Massive interstitial and alveolar hemorrhage was detected in some specimens (Figure 14). Also The interstitial tissue was infiltrated by different inflammatory cells mainly around the bronchovascular bundle and penetrating the bronchial wall to the mucosa (Figure 15). Mononuclear cells formed large aggregates destructing alveolar walls (Figure 16). The lungs of rats treated with MTX and ALA were less severely affected; the interalveolar septa were either mildly thickened or had normal thickness. Pulmonary vasculature was more or less normal except for thickening of some blood vessels wall (Figures 17,18).

Masson's trichrome stain: compared with control (Figure 19) and ALA (Figure 20) groups, marked deposition of collagen fibers in the intersitium, the walls of bronchioles and the wall of blood vessels was seen in the lungs of MTX treated rats (Figure 21). In ALA and MTX group, the interstitial fibrosis was less prominent especially in the alveolar septa of an average thickness (Figure 22).

Caspase immuonohistochemical study: In MTX group strong positive reaction (brown color) was detected in the cytoplasm of pneumocytes, the epithelial lining of bronchioles and the interstitial cellular infiltrate (Figure 25). The reaction was less marked in the MTX \& ALA group (Figure 26) whereas it was minimal in control (Figure 23) and ALA treated (Figure 24) groups.

\section{Morphometry Results}

There was non significant difference regarding the thickness of interalveolar septa, the area percentage of collagen and area percentage of caspase 3 between control and ALA $(P>0.05)$. In the MTX group, those parameters increased significantly $(P<0.001)$. However, in ALA+MTX group, they were significantly $(P<0.001)$ lower (Table 2 , Figures 6,7 and 8).

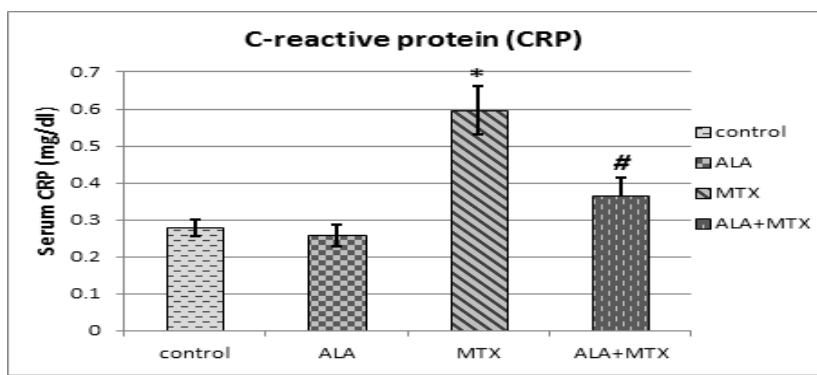

Fig. 1: Simple bar chart showing CRP level in the studied groups $(n=8)$ Analysis was performed using one-way ANOVA, followed by post hoc Tukey test. Values are presented as mean, SE. * Significant difference compared with control group, $P<0.001$, \# significant difference compared with MTX group, $P<0.05$

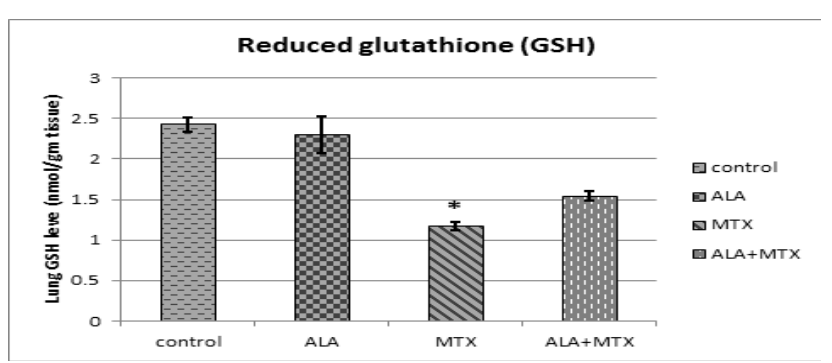

Fig. 2: Simple bar chart showing GSH level in the studied groups $(\mathrm{n}=8)$. Analysis was performed using one-way ANOVA, followed by post hoc Tukey test. Values are presented as mean, SE. * Significant difference compared with control group $P<0.001$ 


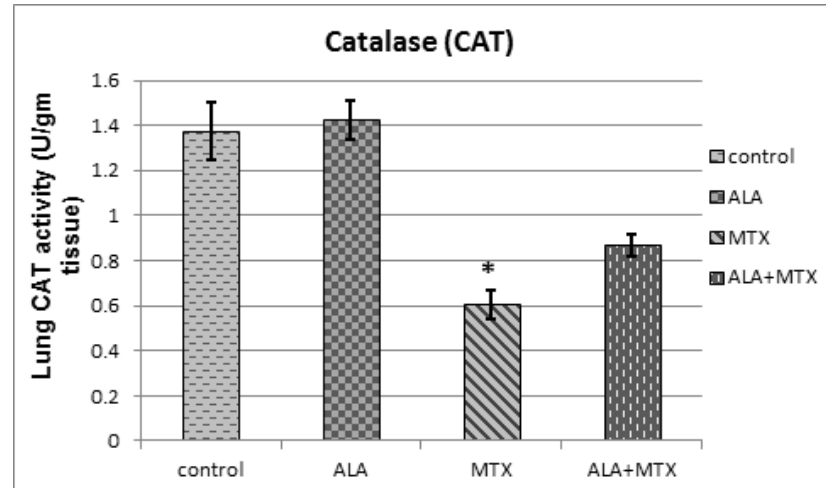

Fig. 3: Simple bar chart showing CAT activity in the studied groups (n $=8$ ). Analysis was performed using one-way ANOVA, followed by post hoc Tukey test. Values are presented as mean, SE. * Significant difference compared with control group, $P<0.001$

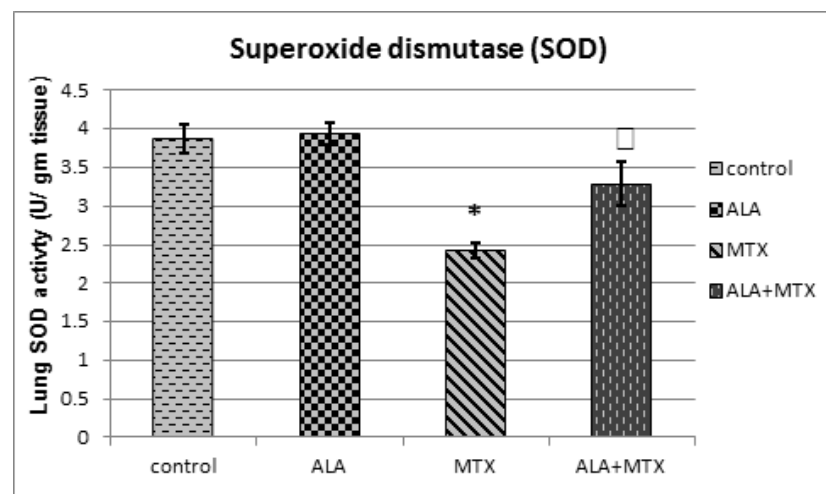

Fig. 4: Simple bar chart showing SOD level in the studied groups $(\mathrm{n}=8)$. Analysis was performed using one-way ANOVA, followed by post hoc Tukey test. Values are presented as mean, SE. * Significant difference compared with control group, $P<0.001$, $\square$ significant difference compared with MTX group, $P<0.05$

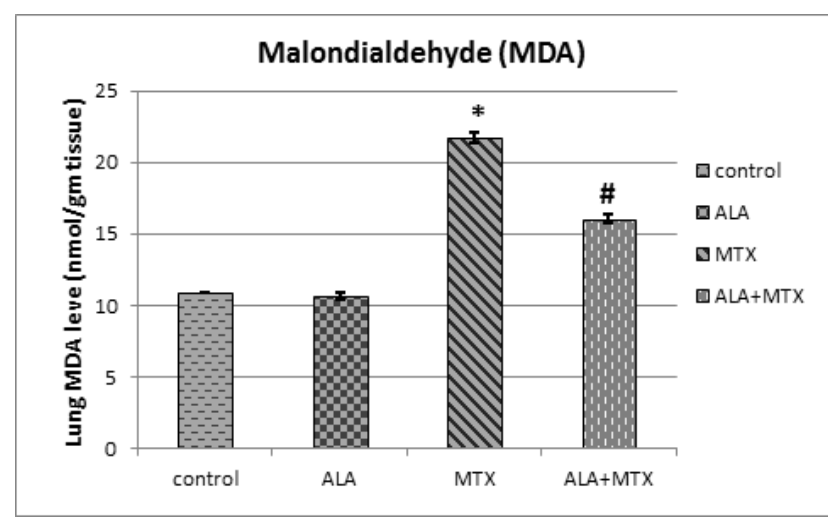

Fig. 5: Simple bar chart showing MDA level in the studied groups ( $\mathrm{n}=$ 8). Analysis was performed using one-way ANOVA, followed by post hoc Tukey test. Values are presented as mean, SE. * Significant difference compared with control group, $P<0.001$, \# significant difference compared with MTX group, $P<0.001$

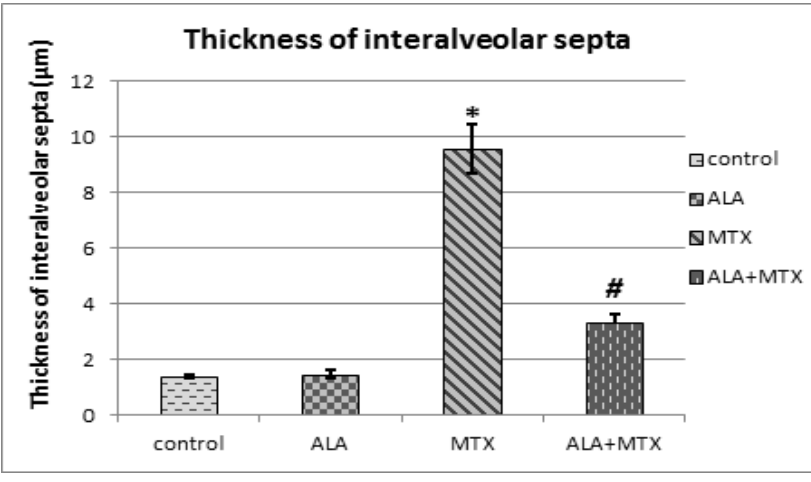

Fig. 6: Simple bar chart showing thickness of interalveolar septa in the studied groups $(n=8)$. Analysis was performed using one-way ANOVA, followed by post hoc Tukey test. Values are presented as mean, SE. * Significant difference compared with control group, $P<0.001$, \# significant difference compared with MTX group, $P<0.001$

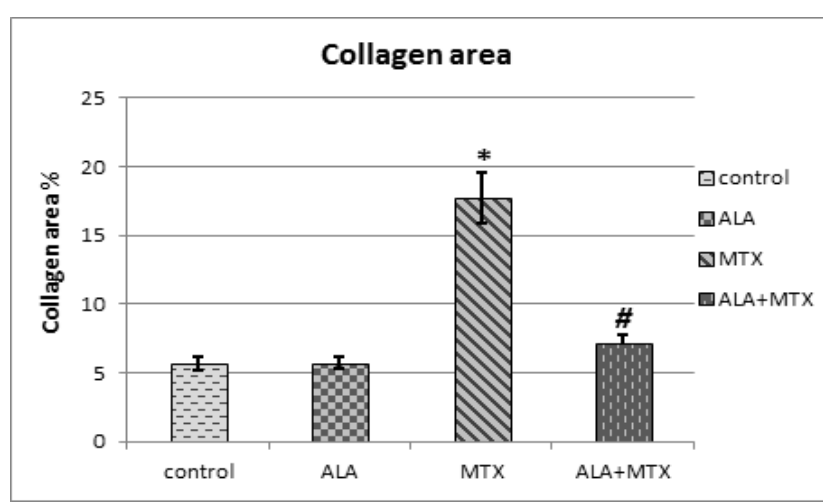

Fig. 7: Simple bar chart showing collagen in the studied groups $(n=8)$. Analysis was performed using one-way ANOVA, followed by post hoc Tukey test. Values are presented as mean, SE. * Significant difference compared with control group, $p<0.001$, \# significant difference compared with MTX group, $p<0.001$

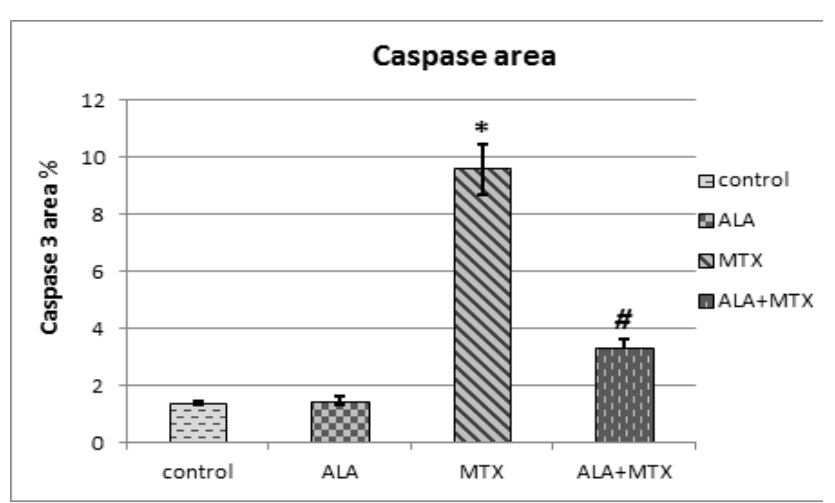

Fig. 8: Simple bar chart showing caspase- 3 area percentage in the studied groups $(\mathrm{n}=8)$. Analysis was performed using one-way ANOVA, followed by post hoc Tukey test. Values are presented as mean, SE. * Significant difference compared with control group, $p<0.001$, \# significant difference compared with MTX group, $p<0.001$ 


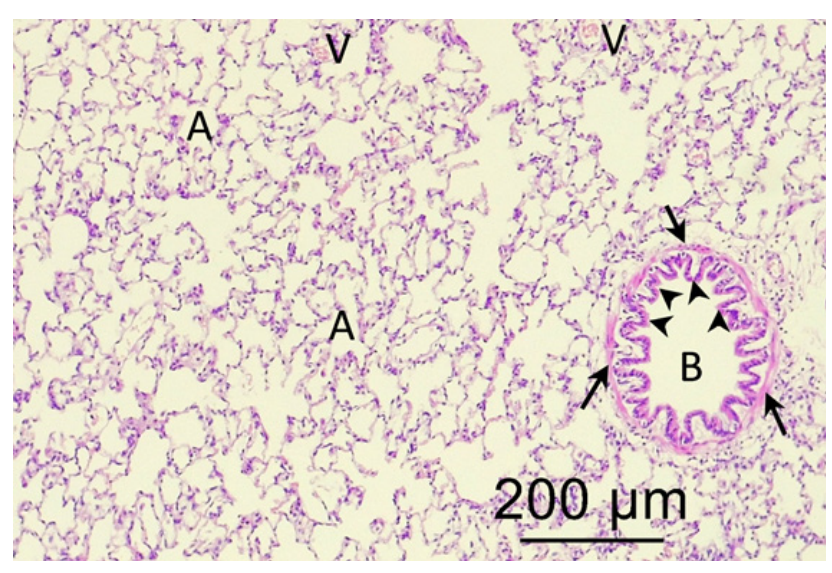

Fig. 9: A photomicrograph of section in the lung of the control group showing alveoli (A), small vessels intervening (V) and medium sized bronchiole (B) with folded lining respiratory epithelium (arrow heads) and regularly arranged surrounding smooth muscles (arrows). (H\&E X 100)

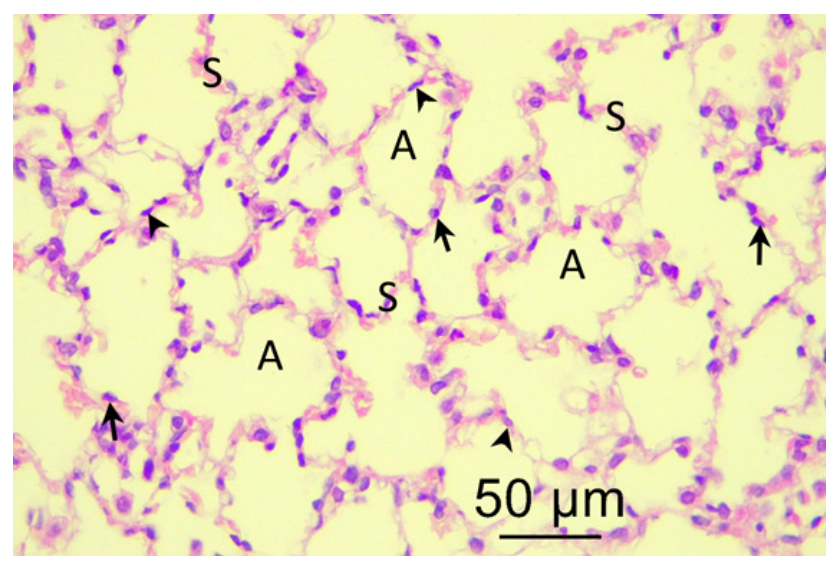

Fig. 10: A photomicrograph of section in the lung of the control group showing multiple alveoli (A) with thin interalveolar septa (S) formed by single layer of cells. Note squamous type I alveolar cells (arrow heads), which line almost the entire alveolus surface and type II alveolar cells bulging into the alveolus (arrows). (H\&E X 400)

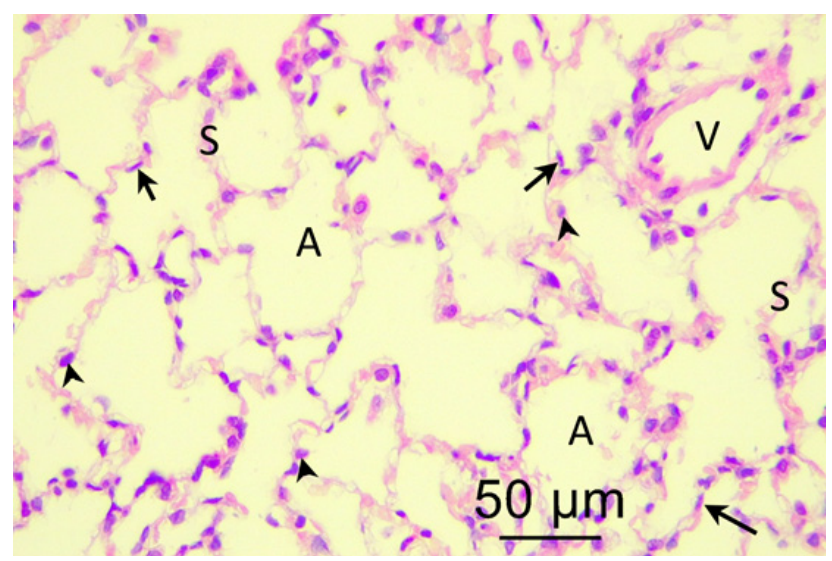

Fig. 11: A photomicrograph of section in the lung of the ALA group showing multiple alveoli (A) with interalveolar septa (S) formed by single layer of cells: type I (arrows), and type II (arrow heads) alveolar cells bulging into the alveolus and small vessels intervening (V). (H\&E X 400)

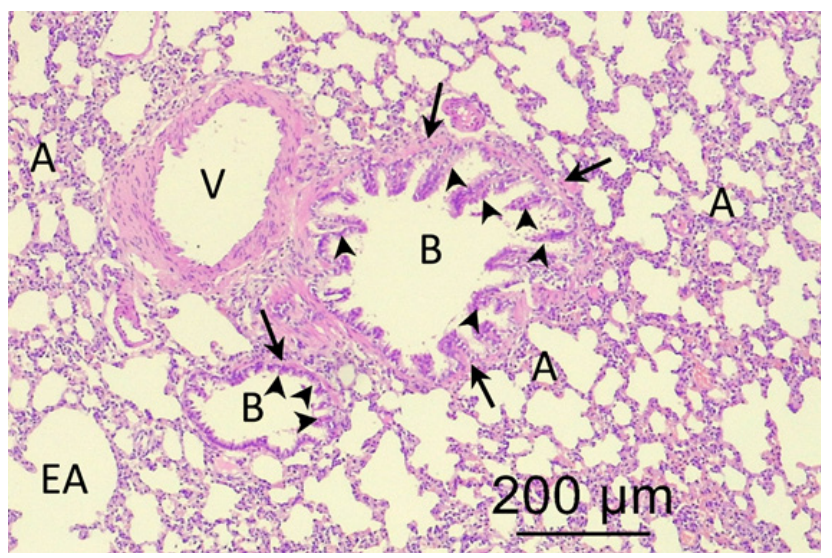

Fig. 12: A photomicrograph of section in the lung of the methotrexate treated group showing different sized bronchioles (B) with denuding of epithelial cells (arrow heads) and disorganized muscle layer (arrows), alveoli (A), widely dilated emphysematous alveolus (EA) and large blood vessel (V) with thickened wall. (H\&E X 100)

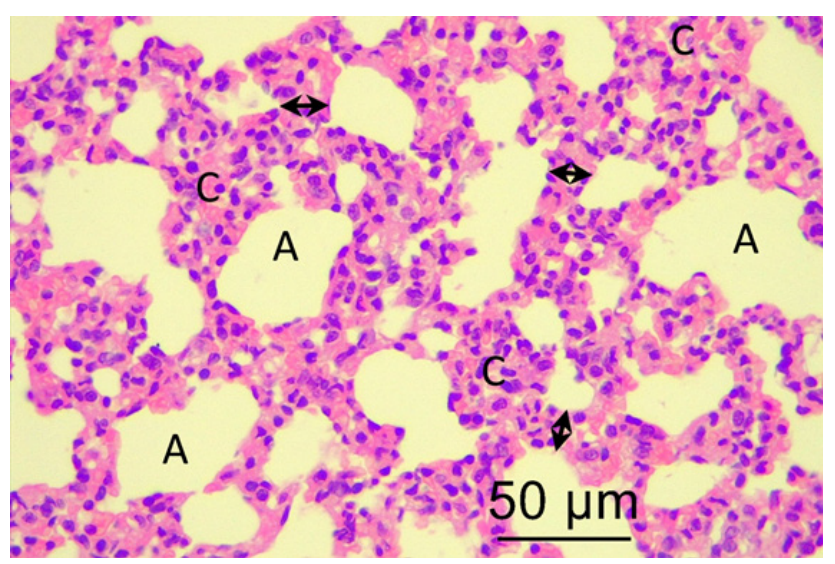

Fig. 13: A photomicrograph of section in the lung of the methotrexate treated group showing air spaces (A) with thick prominent interalveolar septa (arrows) formed by multiple layers of cells and multiple foci of consolidation (C). (H\&E X 400)

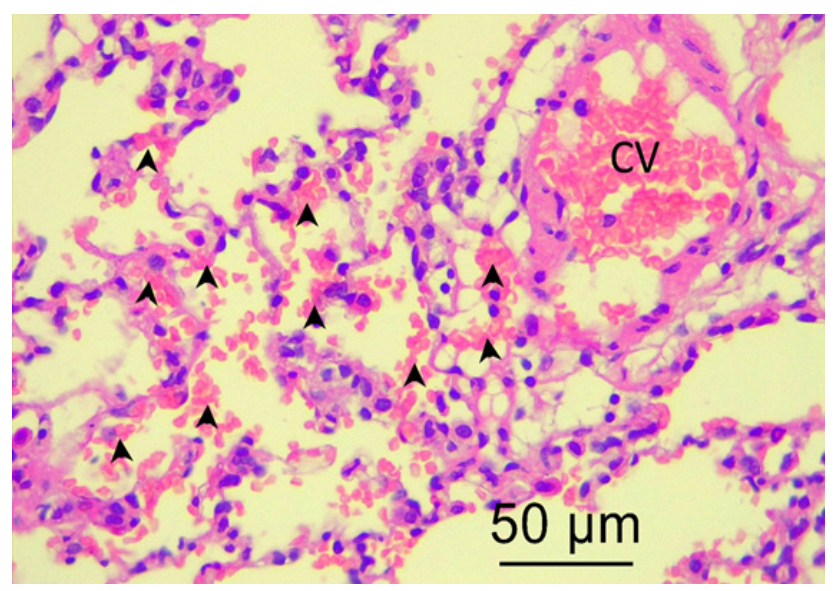

Fig. 14: A photomicrograph of section in the lung of the methotrexate treated group showing massive extravasation of red blood cells (arrow heads) and highly congested blood vessel (V). (H\&E X 400) 


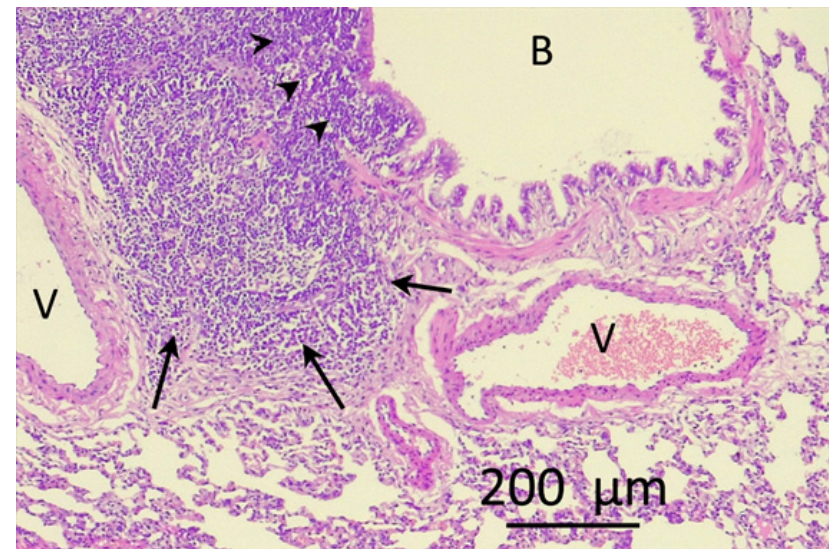

Fig. 15: A photomicrograph of section in the lung of the methotrexate treated group showing bronchovascular bundle (B) \& (V) and in between a large mass of infiltration (arrows) invading the wall of the bronchiole (arrow heads). (H\&E X 100)

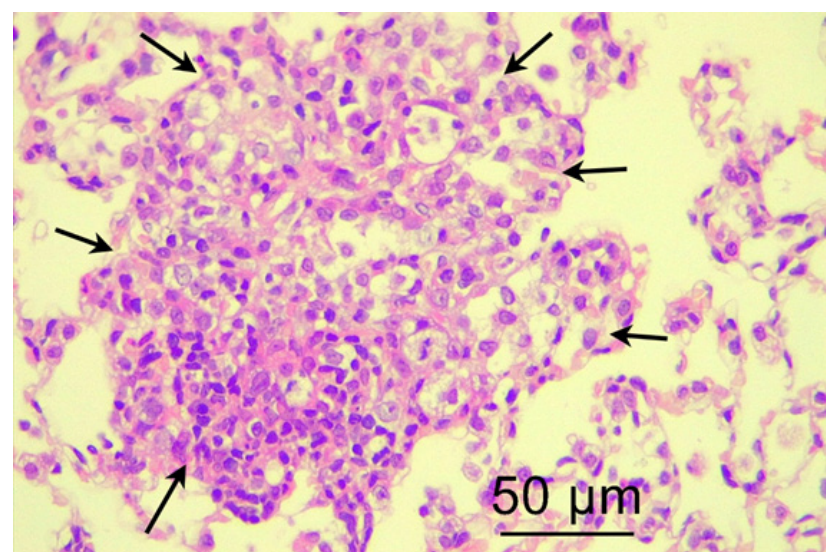

Fig. 16: A photomicrograph of section in the lung of the methotrexate treated group showing granuloma (arrows) destroying the wall of the alveoli and obstructing their cavity. (H\&E X 400)

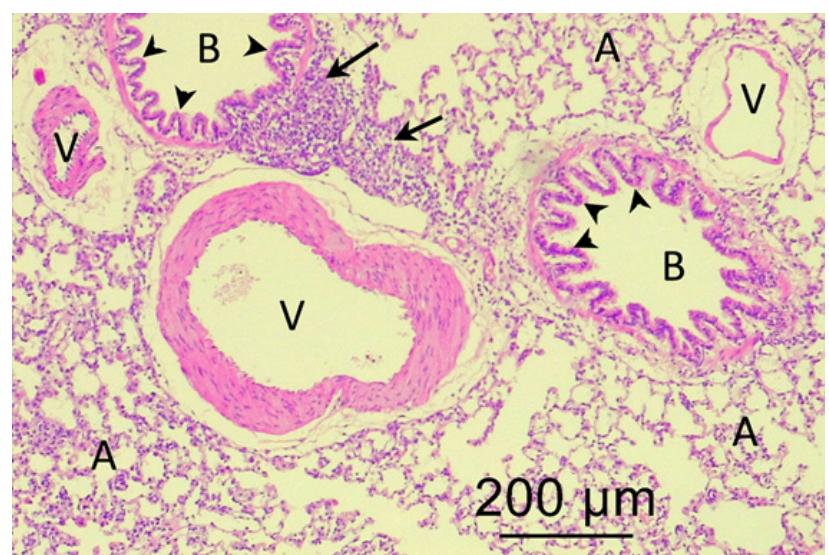

Fig. 17: A photomicrograph of section in the lung of the MTX + ALA treated group showing bronchioles (B) with folded mucosal lining (arrow heads), blood vessels (V) with thick wall and intact intima, alveoli (A) with relatively thin interalveolar septal. Note small mass of infiltration partially invading the wall of one bronchiole (arrows). (H\&E X 100)

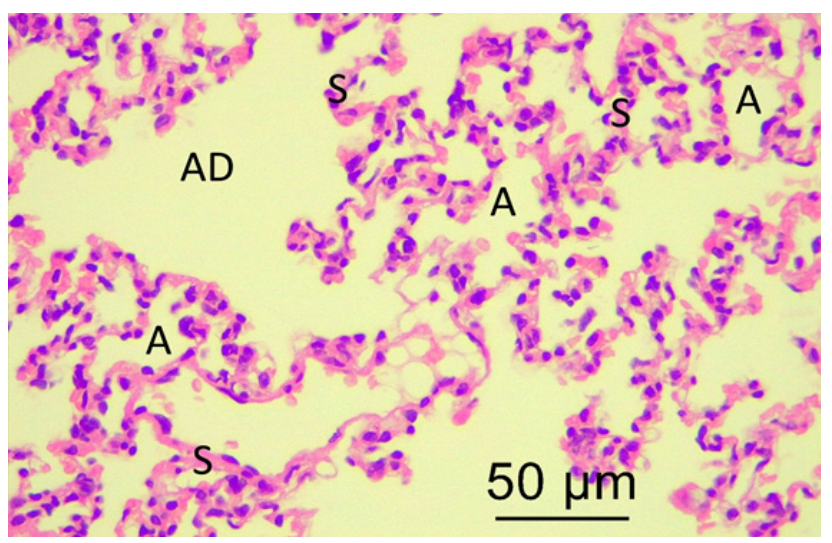

Fig. 18: A photomicrograph of section in the lung of the methotrexate MTX + ALA treated group showing lung tissue with alveoli (A) and alveolar ducts (AD). Note interalveolar septa (S) formed of single layer of cells. (H\&E X 400)

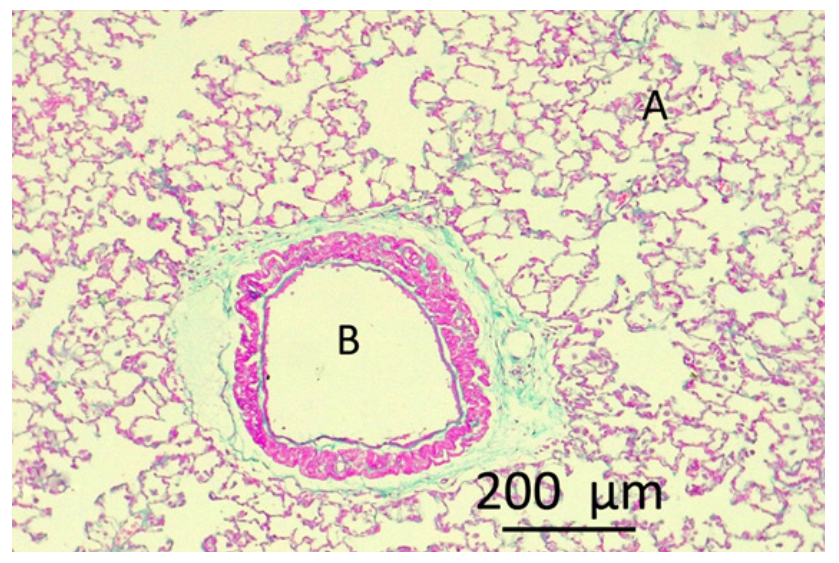

Fig. 19: A photomicrograph of section in the lung of the control group showing (B) with few amount of collagen fibers it its wall. Note the surrounding lung tissue with alveoli (A) showing little amount of collagen fibers (Green) in the interalveolar septa. (Masson's trichrome X 100)

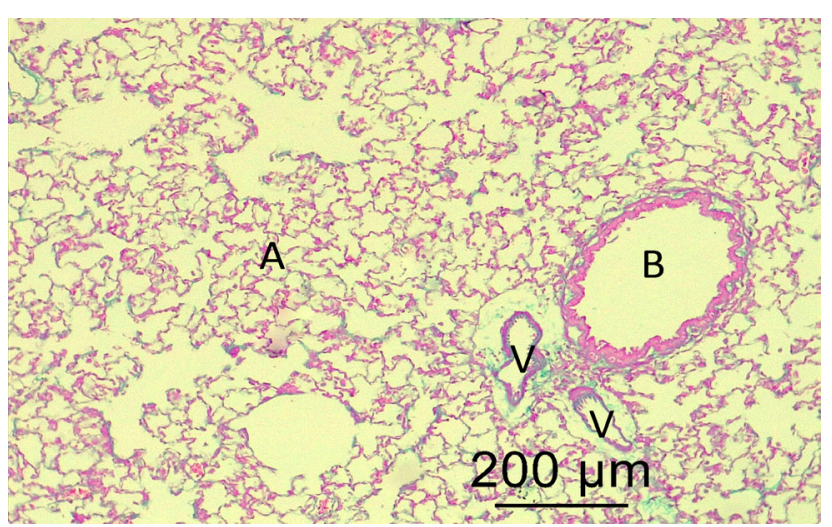

Fig. 20: A photomicrograph of section in the lung of the ALA group showing bronchiole (B) with few amount of collagen fibers (Green) it its wall. In addition, surrounding lung tissue with alveoli (A) and intervening vessels (V) showing minimal amount of collagen fibers (Green) in their walls. (Masson's trichrome X 100) 


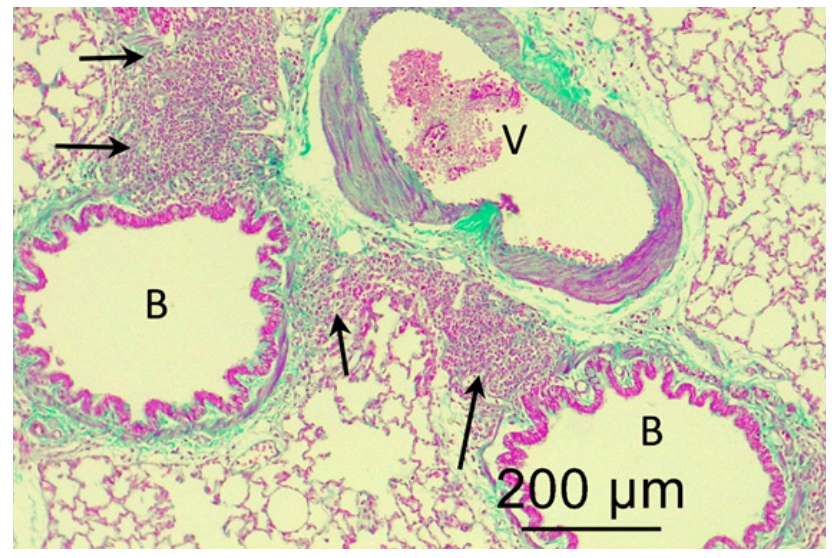

Fig. 21: A photomicrograph of section in the lung of methotrexate treated group showing 2 bronchioles (B) and a blood vessel (V) with abundant content of collagen fibers (Green) it their walls. Note collagen fibers in the cellular infiltrate. (Masson's trichrome X 100)

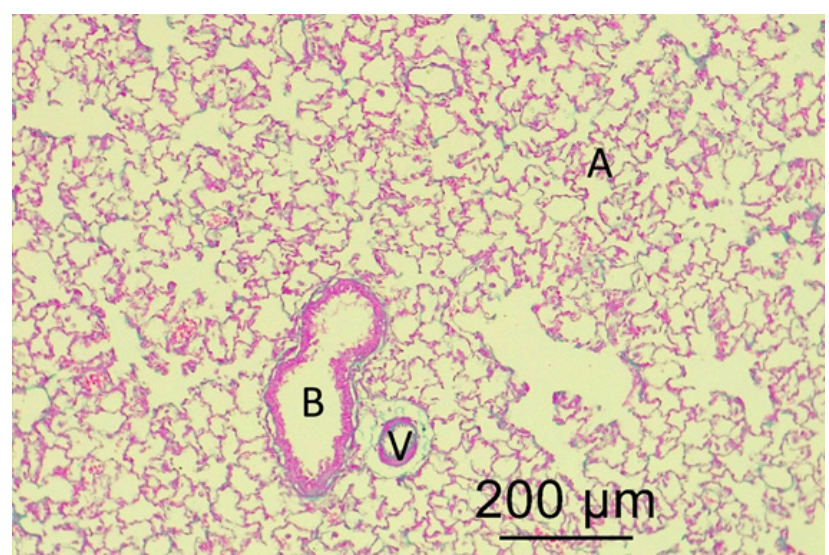

Fig. 22: A photomicrograph of section in the lung of the MTX $+\alpha$ ALA treated group showing small bronchiole (B), blood vessel (V) and alveoli (A) with few amount of collagen fibers (Green). (Masson's trichrome X 100)

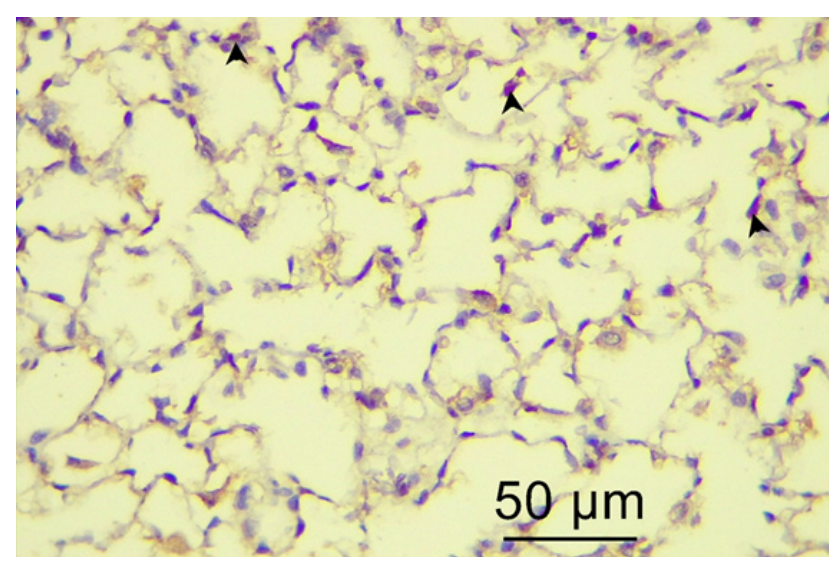

Fig. 23: A photomicrograph of section in the lung of the control group showing interalveolar septa with minimal number of apoptotic cells (arrow heads) (Caspase3 X 400)

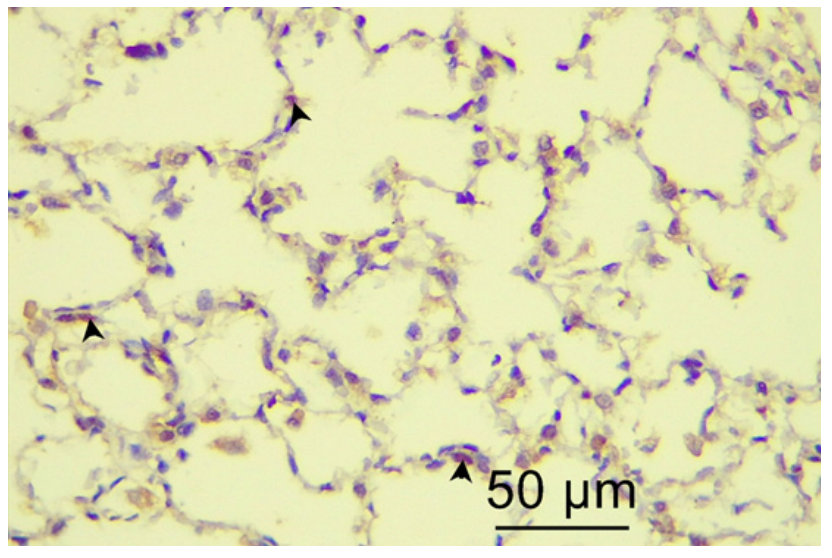

Fig. 24: A photomicrograph of section in the lung of the ALA treated group showing few number of apoptotic cells (arrow heads). (Caspase 3 X 400)

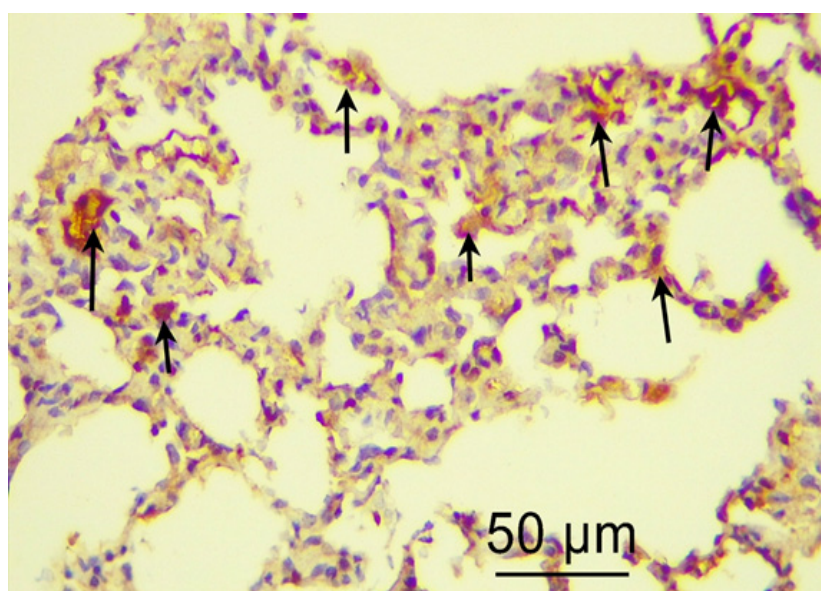

Fig. 25: A photomicrograph of section in the lung of the MTX treated group showing thick interalveolar with several areas of infiltration and consolidation with abundant apoptotic cells (arrows). (Caspase3 X 400)

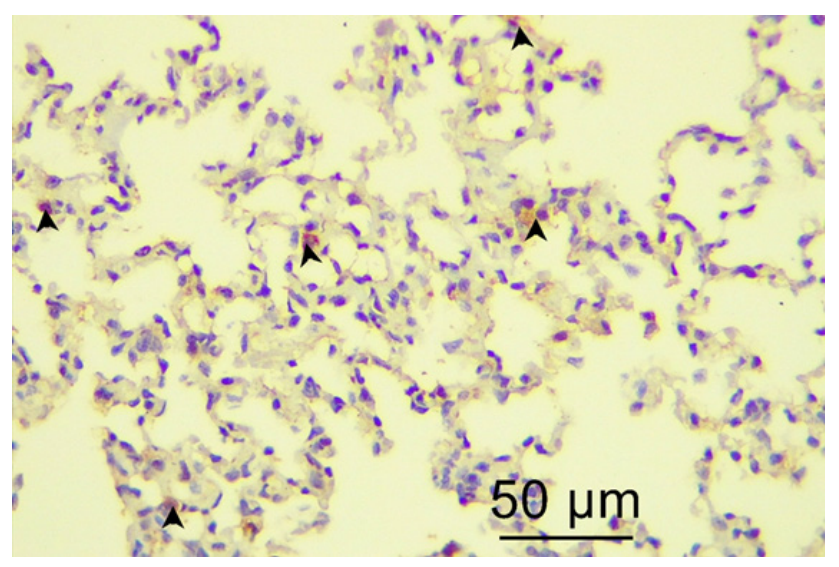

Fig. 26: A photomicrograph of section in the lung of the MTX+ALA treated group showing interalveolar septa with fewer apoptotic cells (arrow heads). (Caspase3 X 400) 
Table 1: Comparison between biochemical results in the different studied groups using ANOVA test

\begin{tabular}{|c|c|c|c|c|c|c|c|}
\hline \multirow[b]{2}{*}{ Parameter } & \multirow[b]{2}{*}{$\begin{array}{c}\text { Control } \\
\text { Mean } \pm \text { SE }\end{array}$} & \multirow[b]{2}{*}{$\begin{array}{c}\text { ALA } \\
\text { Mean } \pm \text { SE }\end{array}$} & \multirow[b]{2}{*}{$\begin{array}{c}\text { MTX } \\
\text { Mean } \pm \text { SE }\end{array}$} & \multirow[b]{2}{*}{$\begin{array}{l}\mathrm{ALA}+\mathrm{MTX} \\
\text { Mean } \pm \mathrm{SE}\end{array}$} & \multirow[b]{2}{*}{ ANOVA } & Post hoc & \multirow{2}{*}{$\begin{array}{c}\text { (Tukey's test) } \\
\text { MTX +ALA } \\
\text { vs MTX }\end{array}$} \\
\hline & & & & & & MTX vs Control & \\
\hline $\mathrm{CPR} \mathrm{mg} / \mathrm{dl}$ & $0.279 \pm 0.023$ & $0.285 \pm 0.030$ & $0.596 \pm 0.065$ & $0.364 \pm 0.052$ & $<0.001 * *$ & $* *$ & $* *$ \\
\hline SOD (U/gm) & $3.873 \pm 0.177$ & $3.930 \pm 0.143$ & $2.423 \pm 0.095$ & $3.287 \pm 0.288$ & $<0.001 * *$ & $* *$ & * \\
\hline CAT (U/gm) & $1.374 \pm 0.125$ & $1.424 \pm 0.088$ & $0.607 \pm 0.064$ & $0.871 \pm 0.049$ & $<0.001 * *$ & $* *$ & ns \\
\hline MDA (nmol/gm) & $10.980 \pm 0.328$ & $10.630 \pm 0.295$ & $21.730 \pm 0.366$ & $16.040 \pm 0.324$ & $<0.001 * *$ & $* *$ & ** \\
\hline GHS (nmol/gm) & $2.429 \pm 0.089$ & $2.303 \pm 0.255$ & $1.173 \pm 0.049$ & $1.549 \pm 0.055$ & $<0.001 * *$ & $* *$ & ns \\
\hline
\end{tabular}

NS statistically non-significant $p>0.05$

ALA: Alpha-lipoic acid group MTX: Methotrexate

Table 2: Comparison between the studied groups regarding morphometric data

\begin{tabular}{|c|c|c|c|c|c|c|c|}
\hline \multirow[b]{2}{*}{ Parameter } & \multirow{2}{*}{$\begin{array}{c}\text { Control } \\
\text { Mean } \pm \text { SE }\end{array}$} & \multirow{2}{*}{$\begin{array}{c}\text { ALA } \\
\text { Mean } \pm \text { SE }\end{array}$} & \multirow{2}{*}{$\begin{array}{c}\text { MTX } \\
\text { Mean } \pm \text { SE }\end{array}$} & \multirow{2}{*}{$\begin{array}{l}\text { ALA+MTX } \\
\text { Mean } \pm \text { SE }\end{array}$} & \multirow[b]{2}{*}{ ANOVA } & \multirow{2}{*}{$\frac{\text { Post hoc }}{\text { MTX vs Control }}$} & \multirow{2}{*}{$\begin{array}{c}\text { (Tukey's test) } \\
\text { MTX +ALA } \\
\text { vs MTX }\end{array}$} \\
\hline & & & & & & & \\
\hline $\begin{array}{l}\text { Thickness of } \\
\text { Inter-alveolar } \\
\text { septa }(\mu \mathrm{m})\end{array}$ & $2.028 \pm 0.126$ & $1.749 \pm 0.080$ & $5.465 \pm 0.439$ & $3.197 \pm 0.092$ & $<0.001 * *$ & $* *$ & $* *$ \\
\hline $\begin{array}{l}\text { Area percentage } \\
\text { of collagen }(\%)\end{array}$ & $5.654 \pm 498$ & $5.727 \pm 0.437$ & $17.700 \pm 1.819$ & $7.144 \pm 0.580$ & $<0.001 * *$ & $* *$ & $* *$ \\
\hline $\begin{array}{l}\text { Area percentage } \\
\text { of caspase-3 }(\%)\end{array}$ & $1.384 \pm 0.077$ & $1.470 \pm 0.143$ & $9.608 \pm 0.884$ & $3.331 \pm 0.289$ & $<0.001 * *$ & $* *$ & $* *$ \\
\hline
\end{tabular}

F one was ANOVA test

\section{DISCUSSION}

MTX is an efficacious chemotherapeutic and immunosuppressive medication. In the vast majority, MTX is well-tolerated. However, it is potentially toxic to an array of organs including liver, intestine, kidneys, bone marrow and lungs ${ }^{[34-36]}$. Pulmonary adverse sequelae of MTX can take place in up to $7 \%$ of patients even they are on a lowdose regimen ${ }^{[8]}$.

Since the clinical, laboratory, radiological and even pathological findings are not pathognomonic, lung lesions due to MTX are problematic for clinicians whereby diagnosis is feasible only after the exclusion of other etiologies ${ }^{[10,37]}$.

It has been suggested that in humans pulmonary toxicity is dose-independent and can occur after MTX intake for once ${ }^{[9]}$. In the animal studies, a single dose of $20 \mathrm{mg} /$ $\mathrm{kg}$ of MTX injected into the peritoneal cavity has been commonly used ${ }^{[14,15,28,38]}$. Regarding ALA, we optioned for the oral route to minimize stress and avoid possible complications from repeated IP injections.

CRP is a classical biomarker in inflammatory conditions. IL-6 and other pro-inflammatory cytokines stimulate the synthesis of such ideal indicator in the hepatic cells ${ }^{[39,40]}$. Although MTX chronotherapy effectively lowered CPR and tumour necrosis factor- $\alpha(\mathrm{TNF}-\alpha)$ in rats with collagen induced-arthritis ${ }^{[41]}$, the highest level of CPR in the present study was in the MTX group. In harmony with our results, CRP and TNF- $\alpha$ were expressed immunohistochemically in the tubular epithelium of MTX-treated rats kidney ${ }^{[13]}$. According to Famurewa, Folawiyo ${ }^{[12]}$, the activation of macrophages nuclear factor kappa $\mathrm{B}(\mathrm{NF}-\mathrm{kB})$ seems to play a role in CRP and IL-6 elevation associated with MTX.

Supporting our results, meta-analysis studies showed that elevated CRP levels dropped significantly in patients supplemented with $\mathrm{ALA}^{[42,43]}$. ALA suppresses the release of inflammatory mediators; IL6 and TNF- $\alpha$; it downregulates the gene responsible for inflammatory cytokines synthesis via keeping NF-k B inactivated ${ }^{[44]}$.

Methotrexate-induced lung injury (MILI) most probably results from flared oxidative stress wherein there is overwhelming of peroxides, superoxide, hydroxyl radical and other reactive oxygen species (ROS) with concomitant depletion of reduced glutathione and different antioxidant enzymes ${ }^{[13,35]}$.

Peroxidation of lipids has been claimed to be a direct impact of MTX ${ }^{[45]}$. MDA is an end product of fat breakdown, thus it is elevated when cellular wall is damaged ${ }^{[24]}$. In line with the results of Kurt et al. ${ }^{[38]}$, MDA level in the present study was significantly elevated in the lung homogenates of MTX injected rats. High levels of MDA were also detected in the cerebellum ${ }^{[45]}$, liver, kidney ${ }^{[28]}$ and testis ${ }^{[15]}$ of MTX-treated rats.

In the MTX group of this study, the activity of SOD and CAT and the concentration of GSH diminished greatly in the pulmonary tissues. Similar alterations in oxidative stress biomarkers have been found in hepatic tissue ${ }^{[46]}$, and 
the sera ${ }^{[12]}$ of rats received the same dose of MTX used in the present study. Kalemci et al. ${ }^{[47]}$ found a significant diminution of pulmonary SOD activity in the rats of the MTX group.

SOD is a metal-containing enzyme highly concentrated in the mitochondria. While SOD is involved in the dismutation of oxygen free radicals to $\mathrm{H}_{2} \mathrm{O}_{2}$, glutathione peroxidase (GPX) promotes the oxidation of GSH to neutralize hydrogen peroxide and reduce oxidized lipids. Before its conversion to the highly injurious hydroxyl radicals, CAT breaks down $\mathrm{H}_{2} \mathrm{O}_{2}$ into $\mathrm{H}_{2} \mathrm{O}$ and $\mathrm{O}_{2}$.

The biochemical findings of the present work revealed that supplementation with ALA has mitigated the oxidative stress in the lung tissue manifested by marked drop in MDA level and enhanced activity of SOD. In another study, there was a restoration of GSH and reduction of MDA in rat's lung tissue when treated with both MTX and ALA $^{[26]}$. The antioxidant activity of ALA was also overt in the liver ${ }^{[24]}$ and testis ${ }^{[15]}$.

ALA enhances the cellular stores of GSH, GPX, SOD and CAT that neutralize oxidative stress toxic products helping cells to survive. A distinctive feature of ALA over other antioxidants is that it boosts energy production and constitutes a cofactor of mitochondrial respiratory enzymes $^{[17,48]}$.

Surprisingly, the elevation in GSH concentration, as well as CAT activity, has not reached a significant level in the ALA+ MTX group. According to Evans and Goldfine $^{[19]}$, ALA is less biologically active when taken orally than when intravenously injected.

The microscopic findings in lung sections of the MTX group in the present work were similar to those observed in lung biopsies taken from patients complaining from MTX-induced pulmonary toxicity ${ }^{[8,11,49]}$. Lung infiltration and septal thickening are common findings in the imaging studies of these patients ${ }^{[9,11]}$. In agreement with Arpag et $a l^{[26]}$, the infiltration of inflammatory cells together with predominance of type II pneumocytes resulted in remarkable thickening of the interalveolar septa which was morphometrically confirmed. According to Kalemci, Akpinar $^{[47]}$ the toxicity of MTX to the lung is mediated through activation of P38 mitogen-activated protein kinases (MAPK). Yang et al. ${ }^{[50]}$ suggested that P38-MAPK plays a central role in inflammatory processes and the production of inflammatory mediators.

Additionally, we noticed congestion and thickening in the wall of blood vessels along with interstitial and intraalveolar hemorrhages. In the experimental study of Kurt et al. ${ }^{[38]}$, the main two histopathological findings in the lungs of MTX-treated rats were: congestion and inflammatory cells infiltration. Hemorrhage, congestion, cellular infiltration and cellular degenerations were prominent features in the livers and kidneys of MTX-treated rats ${ }^{[13,28]}$.

MTX-induced histopathological changes of the lungs have been greatly alleviated in the rats exposed to both MTX and ALA. Pinar et al. ${ }^{[15]}$, explained that ALA has protected the testicles against destructive effect of MTX through inhibition of inflammatory mediators and scavenging ROS. ALA was more effective than pentoxifylline reversing the oxidative-derived damage in the hepatic and renal tissues ${ }^{[28]}$.

In healthy lungs, collagen fibers in the alveolar walls are quite thin, and can only be seen by electron microscopy. Therefore, it is abnormal to detect collagen fibers in routine light microscopy ${ }^{[51]}$. Data from systematic review revealed that interstitial fibrosis comes next after lymphoproliferative disorders as the most common pulmonary complications of $\mathrm{MTX}^{[8]}$. In this study, and in concurrence with Kurt el al. ${ }^{[38]}$ and Kalemci el al. ${ }^{[47]}$, MTX induced a significant increase in area percentage of collagen in Masson's trichrome stained lung sections. Likewise, different grades of lung fibrosis were present in $70 \%$ of rats treated with $\mathrm{MTX}^{[10]}$.

The anti-fibrotic capacity of ALA in this study as evidenced by a significant diminution in area percentage of collagen fibers is probably because of its antioxidant effect as suggested by Yildirim et al. ${ }^{[21]}$ who concluded that ALA decreased the epidural collagen deposition through inhibition the synthesis of IL-6, transforming growth factor- $\beta 1$ (TGF- $\beta 1$ ), plasminogen activator inhibitor-1 (PAI-1) and platelet derived growth factor (PDGF).

In harmony Kurt et al. ${ }^{[38]}$, analysis of data revealed that the expression of caspase- 3 was significantly higher in the MTX group than in the other groups. Caspase- 3 is one of the few robust indicators for detection of apoptotic cells. Upon its activation by various stimuli, a series of signalling sequences end with irreversible, controllable and characteristic morphological changes in the cell ending in its death ${ }^{[52,53]}$. MTX has been found to induce marked apoptosis in the epithelium of jejunum and ileum ${ }^{[6]}$ and increase apoptotic bodies in the hepatic parenchyma ${ }^{[24]}$. Similarly, loss of chondrocytes and osteoblasts and hence bone growth defects have been noticed in the juvenile rat models of MTX chemotherapy ${ }^{[54]}$. According to Samdanci et $a l .{ }^{[35]}$, the MTX-induced apoptotic changes in the hepatocytes were associated with increased MDA levels denoting oxidative peroxidation of cell membrane lipids which is in accordance with our results. Additionally, oxidative stress damages cellular biological molecules such as proteins, lipids, and nucleic acids. Overt oxidative stress usually leads to cell vanish ${ }^{[55]}$. Apart from being an antiproliferative drug, MTX has demonstrated direct toxicity to the cells ${ }^{[5]}$.

Even though it did not significantly change the caspase-3 expression in the spinal cord of ischemic/reperfusion rat models $^{[23]}$, in this study, ALA has significantly decelerated the rate of caspase-3 mediated apoptosis of pneumocytes. Beside its antioxidant and anti-inflammatory properties, Deveci et al. ${ }^{[56]}$ attributed the anti-apoptotic activity of ALA to its ability to inhibit the transient receptor potential Ankyrin 1(TPRA1) in human glioblastoma cells. 
Therefore, we can conclude that ALA was able to counteract the MTX-induced oxidative stress and minimize lung destruction. Consequently, ALA as an adjuvant can lower the risk of pulmonary sequelae of MTX.

\section{ACKNOWLEDGEMENT}

We are grateful to all technicians that participated in this work.

\section{CONFLICTS OF INTEREST}

There are no conflicts of interest

\section{REFERENCES}

1. Conway, R. and J.J. Carey, Methotrexate and lung disease in rheumatoid arthritis. Panminerva Med, 2017. 59(1): p. 33-46.

2. Phillips PC, Dhawan V, Strother SC, Sidtis JJ, Evans AC, Allen JC, et al. Reduced cerebral glucose metabolism and increased brain capillary permeability following high-dose methotrexate chemotherapy: a positron emission tomographic study. Ann Neurol, 1987. 21(1): p. 59-63.

3. Nowicki TS, Bjornard K, Kudlowitz D, Sandoval C, Jayabose S. Early recognition of renal toxicity of high-dose methotrexate therapy: a case report. J Pediatr Hematol Oncol, 2008. 30(12): p. 950-2.

4. Sotoudehmanesh R, Anvari B, Akhlaghi M, Shahraeeni S, Kolahdoozan S. Methotrexate hepatotoxicity in patients with rheumatoid arthritis. Middle East journal of digestive diseases, 2010. 2(2): p. 104-109.

5. Perez-Verdia A, Angulo F, Hardwicke FL, Nugent KM. Acute cardiac toxicity associated with highdose intravenous methotrexate therapy: case report and review of the literature. Pharmacotherapy, 2005. 25(9): p. 1271-6.

6. Koppelmann T, Pollak Y, Mogilner J, Bejar J, Coran A, Sukhotnik I. Dietary L-arginine supplementation reduces Methotrexate-induced intestinal mucosal injury in rat. Vol. 12. 2012. 41.

7. Howard SC, McCormick J, Pui C-H, Buddington RK, Harvey RD. Preventing and Managing Toxicities of High-Dose Methotrexate. The Oncologist, 2016. 21(12): p. 1471-1482.

8. Thaniyan A, Ayman FFA, Mirghani HO, AlSayed BA, Merghani TH. Histopathological Features of Methotrexate Induced Pulmonary Lesions in Rheumatoid Arthritis Patients: A Systematic Review of Case Reports. Open access Macedonian journal of medical sciences, 2017. 5(2): p. 266-270.

9. Chhabra P, Law AD, Suri V, Malhotra P, Varma S. Methotrexate induced lung injury in a patient with primary CNS lymphoma: a case report.
Mediterranean journal of hematology and infectious diseases, 2012. 4(1): p. e2012020-e2012020.

10. Jakubovic BD, Donovan A, Webster PM, Shear NH. Methotrexate-induced pulmonary toxicity. Canadian respiratory journal, 2013. 20(3): p. 153-155.

11. Karadag AS, Kanbay A, Ozlu E, Uzuncakmak TK, Gedik C, Akdeniz N. Pulmonary fibrosis developed secondary to methotrexate use in a patient with psoriasis vulgaris. Northern clinics of Istanbul, 2015. 2(2): p. 159-161.

12. Famurewa AC, Folawiyo AM, Enohnyaket EB, Azubuike-Osu SO, Abi I, Obaje SG, et al. Beneficial role of virgin coconut oil supplementation against acute methotrexate chemotherapy-induced oxidative toxicity and inflammation in rats. Integr Med Res, 2018. 7(3): p. 257-263.

13. Asci H, Ozmen O, Ellidag HY, Aydin B, Bas E, Yilmaz N. The impact of gallic acid on the methotrexate-induced kidney damage in rats. $\mathrm{J}$ Food Drug Anal, 2017. 25(4): p. 890-897.

14. Yucel Y, Oguz E, Kocarslan S, Tatli F, Gozeneli $\mathrm{O}$, Seker A, et al. The effects of lycopene on methotrexate-induced liver injury in rats. Bratisl Lek Listy, 2017. 118(4): p. 212-216.

15. Pınar N, Çakırca G, Özgür T, Kaplan M. The protective effects of alpha lipoic acid on methotrexate induced testis injury in rats. Biomedicine \& Pharmacotherapy, 2018. 97: p. 1486-1492.

16. Ghibu S, Richard C, Vergely C, Zeller M, Cottin Y, Rochette L. Antioxidant Properties of an Endogenous Thiol: Alpha-lipoic Acid, Useful in the Prevention of Cardiovascular Diseases. Journal of Cardiovascular Pharmacology, 2009. 54(5): p. 391-398.

17. Balkis Budin S, Othman F, Louis SR, Abu Bakar M, Radzi M, Osman K, et al. Effect of alpha lipoic acid on oxidative stress and vascular wall of diabetic rats. Rom J Morphol Embryol, 2009. 50(1): p. 23-30.

18. Kurutas EB. The importance of antioxidants which play the role in cellular response against oxidative/ nitrosative stress: current state. Nutrition journal, 2016. 15(1): p. 71-71.

19. Evans JL and Goldfine ID. $\alpha$-Lipoic Acid: A Multifunctional Antioxidant That Improves Insulin Sensitivity in Patients with Type 2 Diabetes. Diabetes Technology \& Therapeutics, 2000. 2(3): p. 401-413.

20. Pari, L. and P. Murugavel, Protective effect of alpha-lipoic acid against chloroquine-induced hepatotoxicity in rats. J Appl Toxicol, 2004. 24(1): p. 21-6. 
21. Yildirim $\mathrm{CH}$, Yucetas $\mathrm{SC}$, Kaya M, Ozic C, Balioglu MB, Ustun $\mathrm{H}$, et al. Alpha-lipoic acid inhibits peridural fibrosis following laminectomy through the inactivation of TGF-beta1, PDGF, PAI-1 and IL-6 expressions. Turk Neurosurg, 2015. 25(1): p. 90-9.

22. Sharma, M. and Y.K. Gupta, Effect of alpha lipoic acid on intracerebroventricular streptozotocin model of cognitive impairment in rats. Eur Neuropsychopharmacol, 2003. 13(4): p. 241-7.

23. Emmez H, Yildirim Z, Kale A, Tonge M, Durdag E, Borcek AO, et al. Anti-apoptotic and neuroprotective effects of alpha-lipoic acid on spinal cord ischemia-reperfusion injury in rabbits. Acta Neurochir (Wien), 2010. 152(9): p. 1591600; discussion 1600-1.

24. Cakir T, Basturk A, Polat C, Aslaner A, Durgut $\mathrm{H}$, Sehirli AO, et al. Does alfa lipoic acid prevent liver from methotrexate induced oxidative injury in rats? Acta Cir Bras, 2015. 30(4): p. 247-52.

25. Tanaka Y, Kaibori M, Miki H, Nakatake R, Tokuhara K, Nishizawa M, et al. Alpha-lipoic acid exerts a liver-protective effect in acute liver injury rats. Journal of Surgical Research, 2015. 193(2): p. $675-683$.

26. Arpag H, Gül M, Aydemir Y, Atilla N, Yiğitcan B, Cakir T, et al. Protective Effects of Alpha-Lipoic Acid on Methotrexate-Induced Oxidative Lung Injury in Rats. Journal of Investigative Surgery, 2018. 31(2): p. 107-113.

27. Namvarpour Z, Nasehi M, Amini A, Zarrindast MR. Protective role of alpha-lipoic acid in impairments of social and stereotyped behaviors induced by early postnatal administration of thimerosal in male rat. Neurotoxicol Teratol, 2018. 67: p. 1-9.

28. Armagan I, Bayram D, Candan IA, Yigit A, Celik $\mathrm{E}$, Armagan $\mathrm{HH}$, et al. Effects of pentoxifylline and alpha lipoic acid on methotrexate-induced damage in liver and kidney of rats. Environ Toxicol Pharmacol, 2015. 39(3): p. 1122-31.

29. Draper, H.H. and M. Hadley, Malondialdehyde determination as index of lipid peroxidation. Methods Enzymol, 1990. 186: p. 421-31.

30. Nishikimi, M., The generation of superoxide anion in the reaction of tetrahydropteridines with molecular oxygen. Arch Biochem Biophys, 1975. 166(1): p. 273-9.

31. Aebi, H., Catalase in vitro. Methods Enzymol, 1984. 105: p. 121-6.

32. Beutler, E., O. Duron, and B.M. Kelly, Improved method for the determination of blood glutathione. J Lab Clin Med, 1963. 61: p. 882-8.
33. Bancroft, J. and M. Gamble, Theory and practice of histological technique. 2008, 6th ed. Churchill Livingston: London.

34. Jariwala P, Kumar V, Kothari K, Thakkar S, Umrigar DD. Acute Methotrexate Toxicity: A Fatal Condition in Two Cases of Psoriasis. Case Reports in Dermatological Medicine, 2014. 2014: p. 3.

35. Samdanci ET, Huz M, Ozhan O, Tanbek K, Pamukcu E, Akatli AN, et al. Cytoprotective effects of molsidomine against methotrexateinduced hepatotoxicity: an experimental rat study. Drug design, development and therapy, 2018. 13: p. 13-21.

36. Zhou B, Xia X, Wang P, Chen S, Yu C, Huang R, et al. Induction and Amelioration of MethotrexateInduced Gastrointestinal Toxicity are Related to Immune Response and Gut Microbiota. EBioMedicine, 2018. 33: p. 122-133.

37. Kileci, J.A., O. Charran, and J. Filopei. Severe Methotrexate-Induced Pulmonary Toxicity, in D34. LUNG TRANSPLANT AND DRUG INDUCED LUNG DISEASE: CASE REPORTS. 2018, American Thoracic Society. p. A6595-A6595.

38. Kurt A, Tumkaya L, Turut H, Cure MC, Cure E, Kalkan Y, et al. Protective Effects of Infliximab on Lung Injury Induced by Methotrexate. Archivos de Bronconeumología (English Edition), 2015. 51(11): p. 551-557.

39. O’Doherty MG, Gilchrist SECM, Young IS, McKinley MC, Yarnell JWG, Gey KF, et al. Effect of supplementation with $\mathrm{B}$ vitamins and antioxidants on levels of asymmetric dimethylarginine (ADMA) and C-reactive protein (CRP): a double-blind, randomised, factorial design, placebo-controlled trial. European Journal of Nutrition, 2010. 49(8): p. 483-492.

40. Sugitharini, V., A. Prema, and E. Berla Thangam, Inflammatory mediators of systemic inflammation in neonatal sepsis. Inflammation Research, 2013. 62(12): p. 1025-1034.

41. Wang X, Yan X, Wang F, Ge F, Li Z. Role of methotrexate chronotherapy in collagen-induced rheumatoid arthritis in rats. Zeitschrift für Rheumatologie, 2018. 77(3): p. 249-255.

42. Akbari M, Ostadmohammadi V, Tabrizi R, Mobini M, Lankarani KB, Moosazadeh $\mathrm{M}$, et al. The effects of alpha-lipoic acid supplementation on inflammatory markers among patients with metabolic syndrome and related disorders: a systematic review and meta-analysis of randomized controlled trials. 2018. 15: p. 39.

43. Saboori S, Falahi E, Eslampour E, Zeinali Khosroshahi M, Yousefi Rad E. Effects of alpha- 
lipoic acid supplementation on C-reactive protein level: A systematic review and meta-analysis of randomized controlled clinical trials. Nutr Metab Cardiovasc Dis, 2018. 28(8): p. 779-786.

44. Moura FA, de Andrade KQ, dos Santos JC, Goulart MO. Lipoic Acid: its antioxidant and antiinflammatory role and clinical applications. Curr Top Med Chem, 2015. 15(5): p. 458-83.

45. Uzar E, Koyuncuoglu HR, Uz E, Yilmaz HR, Kutluhan S, Kilbas S, et al. The Activities of Antioxidant Enzymes and the Level of Malondialdehyde in Cerebellum of Rats Subjected to Methotrexate: Protective Effect of Caffeic Acid Phenethyl Ester. Molecular and Cellular Biochemistry, 2006. 291(1): p. 63-68.

46. Mehrzadi S, Fatemi I, Esmaeilizadeh M, Ghaznavi $\mathrm{H}$, Kalantar H, Goudarzi M. Hepatoprotective effect of berberine against methotrexate induced liver toxicity in rats. Biomed Pharmacother, 2018. 97: p. 233-239.

47. Kalemci S, Akpınar O, Dere Y, Sarıhan A, Zeybek A, Tanriverdi Ö. Efficacy of clarithromycin as a protective agent in the methotrexate-induced pulmonary fibrosis model. Kardiochirurgia i torakochirurgia polska $=$ Polish journal of cardiothoracic surgery, 2018. 15(4): p. 209-212.

48. Devasagayam TP, Tilak JC, Boloor KK, Sane KS, Ghaskadbi SS, Lele RD. Free radicals and antioxidants in human health: current status and future prospects. J Assoc Physicians India, 2004. 52: p. 794-804.

49. Imokawa S, Colby TV, Leslie K, Helmers RA. Methotrexate pneumonitis: review of the literature and histopathological findings in nine patients. Eur
Resp J 15: 373-381. European Respiratory Journal, 2000. 15: p. 373-381.

50. Yang Y, Kim SC, Yu T, Yi Y-S, Rhee MH, Sung $\mathrm{G}-\mathrm{H}$, et al. Functional Roles of p38 MitogenActivated Protein Kinase in MacrophageMediated Inflammatory Responses. Mediators of Inflammation, 2014. 2014: p. 13.

51. Tomashefski, J.F., C. Farver, and A.E. Fraire, Dail and Hammar's Pulmonary Pathology: Volume I: Nonneoplastic Lung Disease. 3rd ed. 2009: Springer New York.

52. Golbs A, Heck N, Luhmann HJ. Luhmann, A new technique for real-time analysis of caspase- 3 dependent neuronal cell death. Journal of Neuroscience Methods, 2007. 161(2): p. 234-243.

53. McIlwain, D.R., T. Berger, and T.W. Mak, Caspase functions in cell death and disease. Cold Spring Harb Perspect Biol, 2013. 5(4): p. a008656.

54. Fan C, Georgiou KR, King TJ and Xian CJ. Methotrexate toxicity in growing long bones of young rats: a model for studying cancer chemotherapy-induced bone growth defects in children. Journal of biomedicine \& biotechnology, 2011. 2011: p. 903097-903097.

55. Li, R., Z. Jia, and M.A. Trush, Defining ROS in Biology and Medicine. React Oxyg Species (Apex), 2016. 1(1): p. 9-21.

56. Deveci HA, Akyuva Y, Nur G and Nazıroğlu M. Alpha lipoic acid attenuates hypoxia-induced apoptosis, inflammation and mitochondrial oxidative stress via inhibition of TRPA1 channel in human glioblastoma cell line. Biomedicine \& Pharmacotherapy, 2019. 111: p. 292-304. 
الملخص العربى

\title{
تاثير حمض الفاليبويك فى تحسين التغيرات الناجمة عن الميثوتريكست فى بنية الرئة فى الجرذ الابيض البالغ
}

\author{
جوزيف أمين عزيز، عبد المولى السيا عيدراوس، أحمد فرج على، محمد صبرى

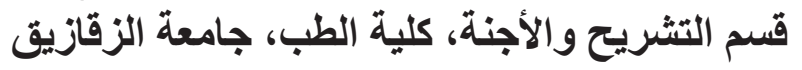

نظرًا لخواصه المضادة للأكسدة والمضادة، تم تقييم حمض ألفا لليويك في مجموعة متنوعة من الأمر اض التنكسية و الار اسات التجريبية المتعلقة بالسمية. الهدف من الدراسة هو تقييم قدرة حمض الفا ليبويك على عكس التغيرات الكيميائية الحيوية والنسيجية التي تحدث في رئة الفئر ان بعد التعرض للميثوتريكسيت.

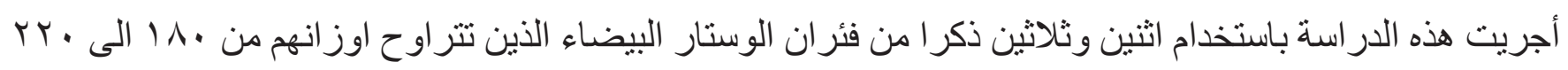
جر ام. تم تقسيم الحيو انات إلى أربع مجموعات متساوية. المجموعة الأولى، المجموعة الضابطة: تلقت الماء المقطر عن طريق الفم لمدة عشرة أيام وحقن 1 مل من محلول ملحي فيزيولوجي (9 ، , ٪ كلوريد الصوديوم) داخل الصفاق في اليوم الر ابع. المجموعة الثانية ، مجموعة حمض الفا ليبويك: تعطى ، . ب مجم من حمض الفا ليبويك مذابا فى الماء المقطر ويتم إعطاؤه بو اسطة أنبوب الفم لمدة عشرة أيام. المجموعة الثالثة ، مجمو عة الميثوتريكسيت: بتم حقن الفئر ان فى هذه المجموعة بجر عة واحدة تبلغ · r مجم من الميثوتريكست لكل كجم داخل الصفاق فى اليوم الر ابع من الدر اسة.

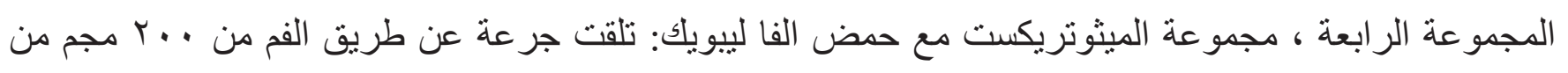
حمض الفا ليبويك مذابا فى الماء المقطر عن طريق انبوب الفم بالاضافة الى حقن ـ مجم لكل كجم من الميثوتريكست داخل الصفاق لمرة واحدة فى اليوم الر ابع. بحلول نهاية التجربة، تم تخدير جميع الحيو انات باستخدام الفينوباربيتال بـ٪. تم جمع عينات الدم لقياس البروتين سي التفاعلي. تم تشريح الرئتين وتجهيز ها لتجانس الأنسجة و الدر اسة النسيجية الروتينية و التقييم المناعي للكاسباس ؟ّ.

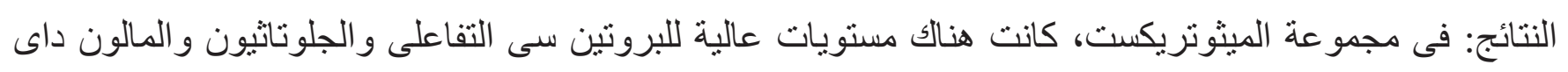
الديهيد مع الحد من أنشطة أنزيمات فوق أكسيد الديسموتاز و الكاتاليز. كثفت شرائح الرئة عن تسلل جلى للخلايا الالتهابية ، زيادة فى سمك الحاجز بين الحويصلات الهو ائية ، احتقان الأو عية الدموية ، نزيف داخل الرئة ، زيادة الياف

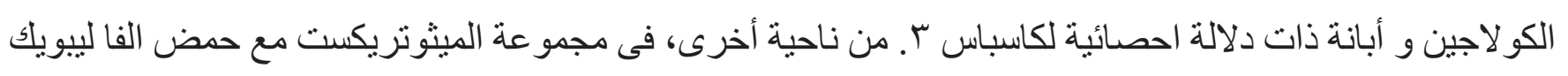
كان هنالك تحسين و اضح فى البنية النسيجية للرئة ونشاط فوق أكسيد الديسميوتاز كما كانت مستويات البروتين سى دئ

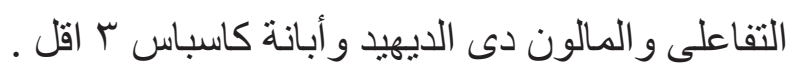
فى الخلاصة أضافة حمض ألفا ليبويك يمكن ان يعمل ضد الضرر التاكسدى فى الرئة الذى يسببه الميثوتريكست. 